\title{
Certificate for Two Days Work on the Dykes (P. Fay. 288 descr.)
}

\author{
Noha Abdelaal Salem \\ Faculty of Arts, Ancient European Civilization Department, \\ Ain Shams University, Egypt \\ nohasalem@ainshams.edu.eg
}

\begin{abstract}
This papyrus text is a certificate for two days work at the embankments on behalf of Euhemeria. Both, the somewhat unexpected extension of only two days of work, as the provenance are of special interest. There are four Penthemeros-certificates coming from Euhemeria up till now.
\end{abstract}

Key Words: Roman Egypt, Euhemeria, Penthemeros-certificates, certificate for two days work, embankments.

\section{P. Cair. Museum. $10837 \quad 8.9 \times 7 \mathrm{~cm} \quad$ AD 147Euhemeria}

The papyrus was described by Grenfell and Hunt in P. Fay. ${ }^{1}$ Descripta of similar content from the P. Fay. volume were published in BASP $54(2017)^{2}$. All the texts were given to us in the frame of the International Seminar on the Cairo Papyri ${ }^{3}$.

The papyrus has kept all its margins and is distinguished by a large lower margin. The writing runs parallel to the fibers; two vertical foldsare visible. A loose fiber in 1. 4 disfigures the letters in the line.

There are two different handwritings: the first hand wrote ll. $1-3$ (mostly the dating formula) with many "Verschleifungen"; the second hand (11. 4-7) is slightly larger, and slightly less cursive; here the work that has been done as well as the worker's name are indicated. ${ }^{4}$ There is no subscription of an administrative body.

The text is a certificate for two days work at the embankments on behalf of Euhemeria. Both, the somewhat unexpected extension of only two days of work, as the

${ }^{1}$ P. Fay. $288=($ P. Cair. Museum. 10837)B.P. Grenfelland A. S. Hunt, Catalogue général des antiquités égyptiennes du Musée du Caire, Oxford, 1903, 105.

${ }^{2}$ Eman A. Abd-Elhady, Usama Gad, Cassandre Hartenstein, Five Penthemeros Certificates from The Cairo Museum, BASP 54 (2017), 59- 82.

${ }^{3}$ The international Seminar on the Cairo Papyri, Sponsored by the Association Internationale de Papyrologues (AIP), in cooperation with the Egyptian Museum, The Center for the Tebtunis Papyri at the University of California, Berkeley, the Institute for the Study of the Ancient World at New York University, The German Archaeological Institute (DAI) and Ain Shams University.

${ }^{4}$ Most of these penthemeros certificates are distinguished by two or three handwritings, since large numbers of certificates issued annually, number of these certificates are written the common formula in advance, and that forms the first hand, while the details such as the date, locality, performer's name were filled later, and forms the second hand. Some texts are subscribed by the administrative signature and this forms the third hand. 
provenance are of special interest. There are four Penthemeros-certificates coming from Euhemeriaso far : P. Hamb. 1.75( AD 149) $\dot{\eta} \Psi v \alpha \lambda \varepsilon i ́ \tau(1 \delta \circ \varsigma) \delta \imath \tilde{\omega} \rho v \xi^{1}$, P. Stras. 4. 249 (AD 158) $\dot{\eta} \Delta \rho v(\mu \varepsilon \imath \tau \hat{\delta} \delta 1) \delta i \tilde{\omega} \rho v \xi^{2}$, P. Ryl. 2. 211( AD 162) $\dot{\eta} \Phi o \lambda \dot{\eta}(\mu \varepsilon \omega \varsigma) \delta 1 \tilde{\omega} \rho v \xi$ and P. Ryl. 2. 212 (AD 162) $\dot{\eta} \Phi о \lambda \eta \dot{\eta}(\mu \varepsilon \omega \varsigma) \delta i \tilde{\omega} \rho v \xi$ two other texts have recently published in

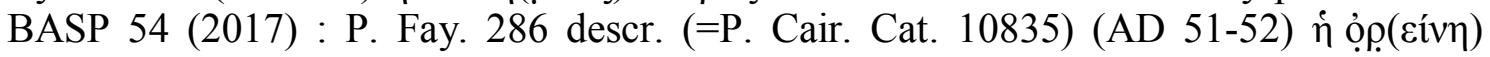
Ḥ $\rho \kappa \lambda(\varepsilon i ́ \delta o v)$ and P. Fay. 290 descr. (= P. Cair. Cat. 10839) ( AD 195) $\dot{\eta} \pi \lambda \omega \tau \grave{\eta}$ Xó̀iкоs.

The common certificates attest five days of work, therefore Penthemeros Certificates; only some texts refer to two days of work (probably extra days above the common five days): ${ }^{3}$ P. Dubl. 9 ( Arsinoite 140 AD);P. Fay. 78 (Theadelphia 147 AD); PSI X 1110 (Theogonis 157/8 AD). P. Teb. II 644 (Teb; $2^{\text {nd }} / 3^{\text {rd }}$ AD); A few texts are certificates for seven days work (the ordinary five days in addition to extra two days): P. Stras. III 155 (Bacchias AD 119); PSI IX 1044 (Soknopaiou Nesos AD 140/1); SB VIII 9224 (Tebtynis AD 141). For discussion and bibliography of such type of documents cf. P.J. Sijpesteijn, Penthemeros Certificates in Greco-Roman Egypt (Pap. Lugd. Bat. XII 1964) and his supplements to it in Aegyptus 52 (1972) 141-151 and BASP 16 (1979) 131. Recent studies on certificates of five day's work are:W. Graham Claytor, Penthemeros Certificates from the Granary C123, Karanis, BASP 50 (2013) and Eman A. AbdElhady, Usama Gad, Cassandre Hartenstein, Five Penthemeros Certificates from The Cairo Museum BASP 54 (2017) p. 62.The new text follows the common formula for such certificates (even for five, two, or seven days of work in the embankment).

\section{Recto:}

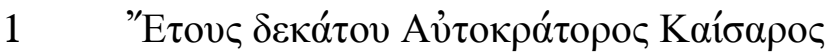

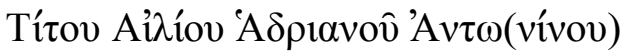

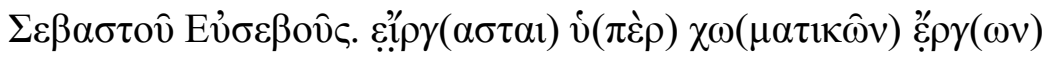

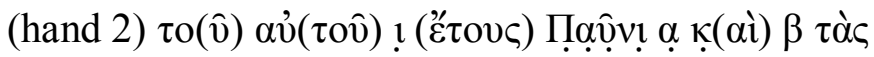

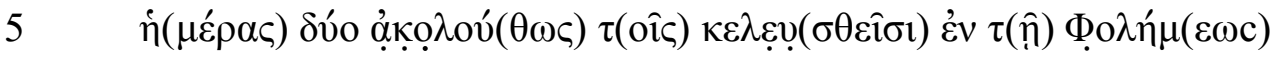

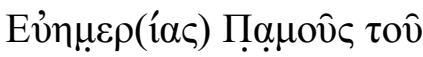

${ }^{e} \mathrm{H}[\rho \omega] \underline{\operatorname{og}(\varsigma) \mu \eta(\tau \rho o ̀ \varsigma)} \Theta \alpha \hat{\tau} \tau(\circ \varsigma)$

In the tenth year of Emperor Caesar Titus Ailius Hadrianus Antoninus Augustus, Pamous son of Heron his mother being Thaus has worked on behalf of the embankment work $\left(2^{\text {nd }}\right.$ hand) for the same tenth year $1^{\text {st }}$ and $2^{\text {nd }}$ of Pauni the two days according to the command in the Pholemis on behalf of Euhemeria.

\section{Commentary:}

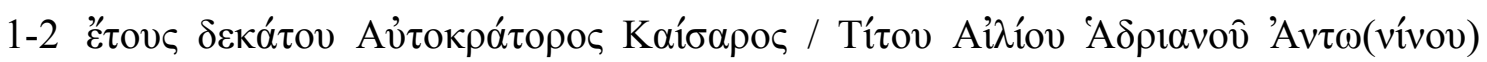
The imperial titulature is, as is usual, written with extreme Verschleifung, Several penthemeros texts are issued in the same tenth year of the emperor Titus Aelius

${ }^{1}$ Cf. BL IV, p. 36, BL V 40 and BL IX 99.

2 Cf. BL V 140.

${ }^{3}$ Cf. P.J. Sijpesteijn, Some remarks on the $\pi \varepsilon v \theta \eta \dot{\mu \varepsilon \rho \rho} \varsigma$-covrée, ZPE 64,1986,127. 
Hadrianus Antoninus (AD 138-161: P. Fay. 77; P. Fay. 78; P. Metr. II 69; SB VI 9437 and SB XVI 12318.

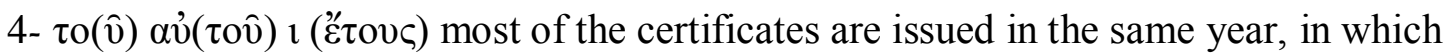
the work was done; cf. P. J. Sijpestein, (Pap. Lugd. Bat. XII 1964), p. 10.

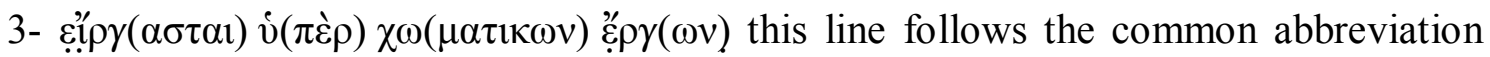
style of the formula. Sometimes eis is followed by the accusative instead of $\dot{v}(\pi \dot{\varepsilon} \rho)$ with

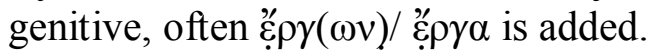

4- Пִ̣̣̂v! The reading comes very difficult as the papyrus suffers crimp. Pauni is attested several times as the working month in this kind of certificates. Certificates seem to be mostly issued from Pauni to Mesore and decrease gradually up to Choiak. This is due to the level of the Nile which is suitable for embankment works in mid of June. Cf. G. Claytor, BASP 50, pp. 49-75, no. 4, 1. 4.

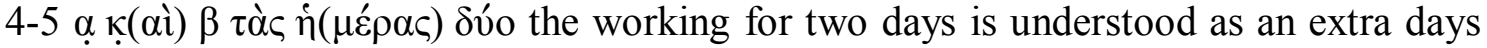
work on embankment works. The use of the article to show that those are extra two days cf. P.J. Sijpesteijn, ZPE 64, 1986, 127.For such of these two days; see above in introduction.

6- The reading of the beginning of this line seems clear, the abbreviated $\dot{\eta}\left(\mu \varepsilon^{\prime} \rho \alpha \varsigma\right)$ followed by the number of the extended days $\delta$ ó. Texts of extra days work on dikes

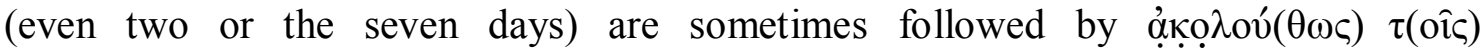

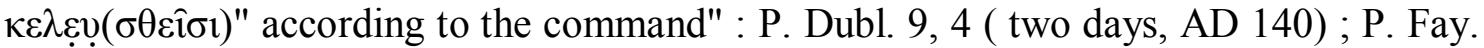
78, 5 ( two days, AD 147); PSI IX 1044 (seven days, AD 141); P. Strasb. Gr. I 18, 4-5 (seven days, AD 141), SB VIII 9924, 4 ( seven days, AD 141), SB XVIII 13978 (two days, AD 138-161?). it is noticed that this phrase is usually followed by the date in which the work has been done.

After that it is expected to mention the name of the canal on behalf of the locality where the work is carried out. $\dot{\varepsilon} v \tau(\hat{n}) \Phi \circ \lambda \hat{n} \mu(\varepsilon \omega \mathrm{c})$

$\dot{\varepsilon} \nu \tau(\hat{n}) \Phi \circ \lambda \eta \dot{n} \mu(\varepsilon \omega c)$ It is notable that the canal's name sometimes is preceded or followed by $\delta i \omega(\rho v \gamma l)$ and other times it comes mere without $\delta i \omega(\rho v \gamma l)$. The name of

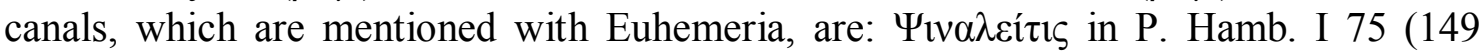

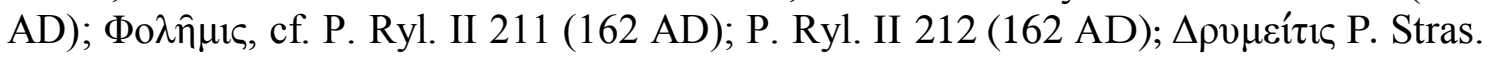
IV 249 (115 AD).

A canal, with the same name, is mentioned as a work place for people from Tebtynis, Euhemeria,Theadelphia, or elsewhere, cf. P. J. Sijpesteijn and K. A. Worp, Six Dyke Certificates, BASP 16 (1979), p. 132; F. W. Jenkins, Two Documentary Papyri, ZPE 59 (1985) p. 34.

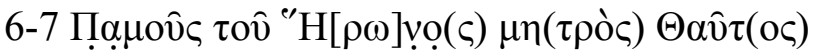

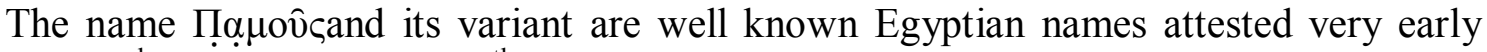
from $2^{\text {nd }} \mathrm{BC}$ and endure till $8^{\text {th }} \mathrm{AD}$.

7- $\mu \eta(\tau \rho o ̀ \varsigma) \Theta \alpha \tilde{\tau}(o \varsigma)$ this Egyptian name Thaus is attested from $\mathrm{BC} 3^{\text {rd }}$ to $2^{\text {nd }} \mathrm{AD}$ cf. $\mathrm{P}$. Col. II 1 (Theadelphia, AD 134-135)

It is remarkable that although the lower margin is large, it lacks the issuer name, for such documents without signature see, H. C. Youti, Notes on O. Mich. I, TAPA 71 (1940), p. 626, note 21 . 


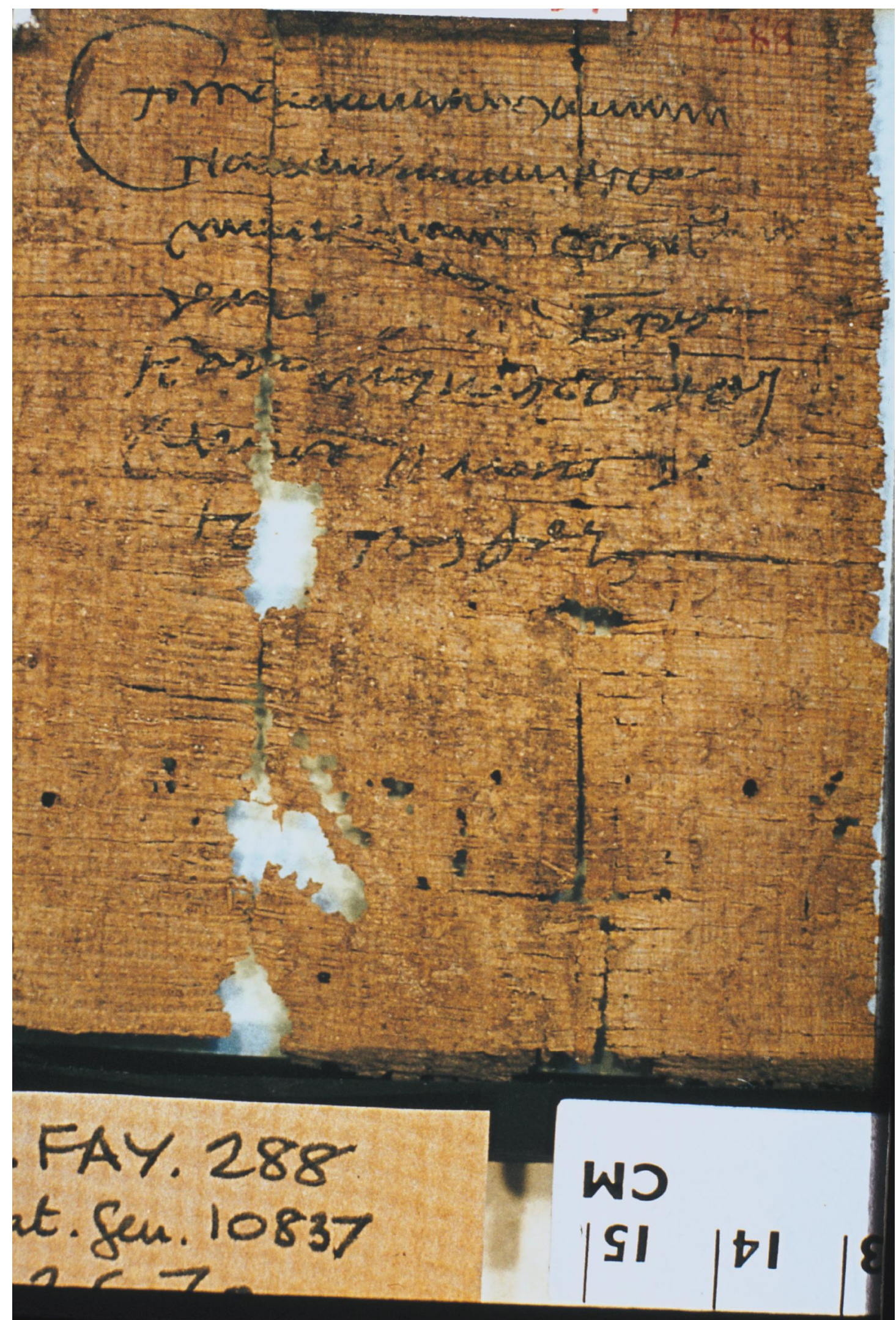

